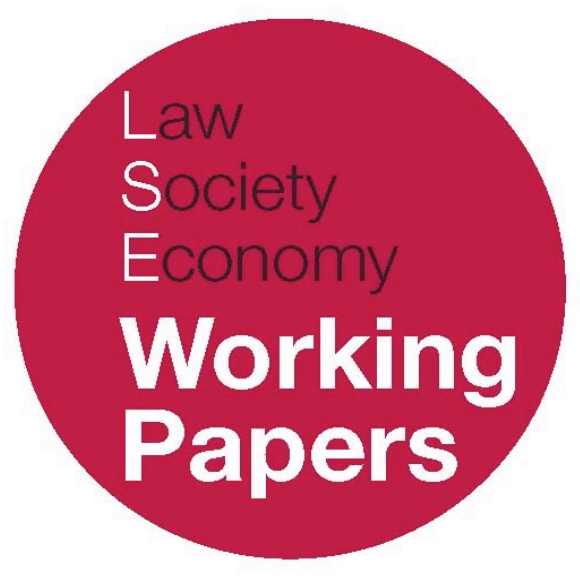

\title{
The Political Constitution Revisited
}

\author{
Martin Loughlin \\ LSE Law, Society and Economy Working Papers 18/2017 \\ London School of Economics and Political Science \\ Law Department
}

\footnotetext{
This paper can be downloaded without charge from LSE Law, Society and Economy Working Papers at: www.lse.ac.uk/collections/law/wps/wps.htm and the Social Sciences Research Network electronic library at: https://ssrn.com/abstract $=3077947$

(C) Martin Loughlin. Users may download and/or print one copy to facilitate their private study or for non-commercial research. Users may not engage in further distribution of this material or use it for any profit-making activities or any other form of commercial gain.
} 


\title{
The Political Constitution Revisited
}

\author{
Martin Loughlin *
}

\begin{abstract}
In his 1978 Chorley Lecture on 'the political constitution', John Griffith presented a critical appraisal of contemporary trends in British constitutional thinking from a functional perspective. This lecture has recently been revived by a new generation of public law scholars as the founding text of an emerging school of 'political constitutionalism'. In this paper, I argue that today's political constitutionalists have distorted Griffith's method and thereby misconstrued its significance. In doing so, they have also obscured the orientation of their movement.
\end{abstract}

\footnotetext{
* Professor of Public Law, London School of Economics \& Political Science. This paper was presented at the MLR sponsored seminar 'Forty Years on from "The Political Constitution": Reflections on Law, Politics and Authority in JAG Griffith's Chorley Lecture' held at the School of Law, University of Sheffield, 13-14 September 2017. I thank the organisers, Professor Graham Gee and Dr Chris McCorkindale, for their invitation and the participants for their comments.

This paper can be downloaded without charge from LSE Law, Society and Economy Working Papers at: www.lse.ac.uk/collections/law/wps/wps.htm and the Social Sciences Research Network electronic library at: https://ssrn.com/abstract $=3077947$

(C) Martin Loughlin. Users may download and/or print one copy to facilitate their private study or for non-commercial research. Users may not engage in further distribution of this material or use it for any profit-making activities or any other form of commercial gain.
} 


\section{INTRODUCTION}

On 10 May 1977 Lord Wedderburn of Charlton, the newly ennobled General Editor of The Modern Law Review, wrote to John Griffith inviting him to give the 1978 Chorley Lecture. Noting that there had been no lecture on public law since its inauguration in 1972, Wedderburn expressed the Editorial Committee's unanimous view that Griffith be invited to speak on some such aspect, adding that Otto Kahn-Freund was especially keen to have him speak on British developments under the title of 'the living constitution'. Griffith responded in typical fashion. 'I have tried to think of an excuse which would enable me, decently and graciously, to decline', he wrote, 'like an incommoding sickness which I expect to contract next spring, or my advanced years which must even now be encouraging the Great Reaper to spit on his scythe'. But he then, of course, courteously accepted. It would appear that he also agreed to give the lecture on 'the living constitution' because in the spring of 1978 a poster advertising it under this title was produced in proof. ${ }^{1}$

Once Griffith turned his attention to the substance of the lecture, however, he soon realised that this title would not do, and at a relatively late stage altered it to The Political Constitution'. ${ }^{2}$ This is not surprising; 'the living constitution' evokes an evolutionary metaphor which derives from Bagehot, ${ }^{3}$ and this hardly fitted Griffith's method. Besides, he regarded Bagehot's book as a fake, or as he puts it in the lecture an 'unhappily misleading' work. ${ }^{4}$ As a scholar much influenced by the methods of legal realism, Griffith sought to focus on facts and avoid metaphor. But in speaking figuratively he found greater clarity in mechanical rather than organic terminology. His amended title provides a significant clue to the thesis he intended to promote in the lecture. Converting constitutional ideas into political realities, his aim was to provide an appraisal of recent constitutional developments from the perspective of political science.

\section{THE THESIS OF THE LECTURE}

Griffith's general approach to constitutional questions is made clear in the opening words of Dieter Grimm's recently published essays on Constitutionalism. Grimm writes:

Every political unit is constituted, but not every one of them has a constitution. The term 'constitution' covers both conditions, but the two are not the same. The term has two different meanings. Constitution in the first sense of the word refers to the nature of a country with reference to its political conditions. Constitution in the second sense refers to a law that concerns itself with the establishment and exercise of political rule. Consequently, the first definition refers to an empirical or descriptive constitution and the second a normative and prescriptive concept. Used

\footnotetext{
1 This information is retrieved from the LSE Archive, Modern Law Review. 'Chorley Lecture - Various, 1970-81'. Ref No: MLR/4/1. I am grateful to Dr Samuel Tschorne for his help in acquiring the material.

2 The archive material includes a copy of the poster proof with this change in what recognisably is Griffith's hand.

${ }^{3}$ Walter Bagehot, The English Constitution RHS Crossman ed. (London: Fontana, 1963), 267: 'There is a great difficulty in the way of a writer who attempts to sketch a living Constitution - a Constitution that is in actual work and power.' " JAG Griffith, 'The Political Constitution' (1979) 42 MLR 1-21, at 2. Subsequent page references in the text refer to this article.
} 
empirically, constitution reflects the political conditions that in fact prevail in a specific region at a given time. In the normative sense, constitution establishes the rules by which political rule should be exercised under law. 5

Griffith would have accepted that account. He recognised that the British constitution is not a constitution in the normative sense; it is a descriptive concept that 'reflects the political conditions that in fact prevail ... at a given time'. His use of the term 'political constitution' signals his intention to present an appraisal of British constitutional arrangements by reference to 'its political conditions'.

In words that recall the terms of the MLR Committee's invitation, Griffith begins the lecture by explaining why a balancing metaphor of 'hold[ing] even the scales of constitutionalism' is inappropriate (p.1). It is so, he says, because 'conflict is at the heart of modern society' and government is necessarily authoritarian (p.2). Coming of age in the 1930s, Griffith adopted the sociological positivism of Comte, Durkheim and Duguit that was then influential in LSE circles. He aimed to free himself from 'the tentacles of the natural lawyers, the metaphysicians and the illusionists' who peddle fancy theories of constitutions and in its place he sought to discover 'where the reality of political and economic power lay' (pp.5-6). His is a thoroughly practical orientation that recognises the fact of social interdependence, focuses on the relationship between law and power, and treats constitutional law simply as an account of the law of public institutions (p.6).

In the lecture he warns that this practical orientation is being displaced by the resurgence of natural law theories 'advanced by both Conservatives and Liberals' (p.7). Such theories, he explains, are implicit in the advocacy by Lords Hailsham and Scarman of the need for a new constitutional settlement (pp.7-10), the juristic underpinning of which can be found in Ronald Dworkin's rights-based conception of law (pp.10-12). ${ }^{6}$ His objections are both political and philosophical. The political objection is that a rights-based method, especially once reinforced by incorporat[ing] the European Convention into our domestic law' (p.14), leaves political conflicts to be determined by the legal profession 'as they embark on the happy and fruitful exercise of interpreting woolly principles and even woollier exceptions' (p.14). The philosophical objection is that law is being 'raised from its proper and useful function as a means to an end ... to the level of a general concept' (p.15).

Griffith is especially critical of the 'value of the exercise of telling judges or other legislators that they should look towards the ideals of justice, truth or beauty in their search for the right solution to difficult cases or problems' and even more so of urging them 'to look to the moral standard of the community' because, he says, 'I do not believe these things exist' (p.12). His point is illustrated by reference to the idea of the 'rule of law'. The term makes sense when it is taken to mean that there should be rules and machinery 'for dealing with criminal offences and ensuring that public authorities do not exceed their legal powers' but 'when it is extended to mean more than that, it is a fantasy invented by Liberals of the old school in the late nineteenth century and patented by the Tories to throw a protective sanctity around certain legal and political institutions and principles which they wish to preserve at any cost' (p.15).

\footnotetext{
5 Dieter Grimm, Constitutionalism: Past, Present, and Future (Oxford: Oxford University Press, 2016), 3.

${ }^{6}$ See, Lord Hailsham, The Dilemma of Democracy (Glasgow: Collins, 1977); Lord Scarman, English Law: The New Dimension (London: Stevens, 1974); Ronald Dworkin, Taking Rights Seriously (Cambridge, MA: Harvard University Press, 1977). Dworkin responds directly to Griffith in his A Matter of Principle (Cambridge, MA: Harvard University Press, 1985), ch.1 'Political Judges and the Rule of Law'.
} 
Griffith concludes the lecture by emphasising that 'laws are merely statements of a power relationship' (p.19), that 'law is not and cannot be a substitute for politics' and that 'political decisions should be taken ... by people who are removable' (p.16). The resurgence of natural law is dangerous because it involves an elitist trade in abstractions, because it leads to those holding political power being given 'moral right or moral authority', and because it mistakenly converts political claims into fundamental rights (pp.16-17). The constitution, he emphasises, is an empirical phenomenon; it 'lives on, changing from day to day for the constitution is no more and no less than what happens' (p.19).

\section{ORIGINALITY OF THE THESIS}

Since it is relatively well known, I have been concise in presenting the lecture's basic thesis. What is less appreciated is its originality, and in this regard I want to make two claims.

The first is that the lecture contains no new political, philosophical or methodological insights. It is both engaging and entertaining but, as his earliest scholarly publications show, Griffith used the Chorley Lecture to showcase arguments he had been consistently making over the previous thirty years. His work from the early 1950s on Parliament and legislation, for example, display a mature public law method already at work. We find him explaining that 'the constitution is perpetually changing' and that as 'the nature of the constitution changes, the load of power shifts, and the functions of the various bodies change'. ${ }^{7} \mathrm{He}$ also argues that because of this distinctive feature of the British constitution those who theorise about the constitution end up distorting it. 'The theory of the constitution', he maintains, 'is full of ghosts striving to entangle us with their chains' ${ }^{8}$ Because the constitution is 'a flexible instrument', ${ }^{9}$ and the 'theory of the constitution is the rationalisation of events', ${ }^{10}$ there is 'a great danger of constitutional theory lagging far behind constitutional practice'. ${ }^{11}$ Constitutional analysis should never be undertaken from the vantage point of some idealised version but should focus on the way governing arrangements meet 'the needs of the day', that is, 'by a functional not an a priori approach'. ${ }^{12}$

The rigorous positivist and functionalist method that drives his argument in 'The Political Constitution' was fully formed by the early 1950s. According to this method, theory must never be permitted to distort understanding of 'the "what actually happens" constitution'. ${ }^{13}$ We also see him asserting that law is not a norm: it is a social fact. Law is 'a social science, part of the social order, dealing with private rights and public necessities and the conflicts between them' and it is subject to evaluation only by showing that 'the legal rules do not effect what they purpose' or that they 'work in such a way that the interests of certain individuals or groups (private and public) are advanced to the disadvantage of other

\footnotetext{
${ }^{7}$ JAG Griffith, 'The Constitutional Significance of Delegated Legislation’ (1950) 48 Michigan Law Review 1079-1120, at 1092.

${ }^{8}$ JAG Griffith, 'The Place of Parliament in the Legislative Process: Part II' (1951) 14 Modern Law Review 425-436, at 436.

9 JAG Griffith, 'The Place of Parliament in the Legislative Process. Part I' (1951) 14 Modern Law Review 279-96, at 279.

${ }^{10}$ Griffith, 'The Constitutional Significance of Delegated Legislation', above n.7, at 1118.

${ }^{11}$ Griffith, 'The Place of Parliament in the Legislative Process. Part I', above n.9, at 279.

12 Ibid.

${ }^{13}$ JAG Griffith, 'Justice and Administrative Law Revisited' in JAG Griffith (ed), From policy to administration: essays in bonour of William A. Robson (Allen \& Unwin 1976), 200-16, at 204-5.
} 
individuals or groups'. ${ }^{14}$ And with respect to this second type of evaluative exercise, he emphasises that 'I should clearly indicate my personal or philosophic presumptions and assumptions'. ${ }^{15}$

This realist and functionalist method determines his well-known critique of the judiciary. He recognises that judges have an important technical role to perform but he also emphasises that they are human and as such have political views. As he wrote in the 1960s: 'They say and believe that distinctions can be made between matters apt for the courts, and matters apt for Parliament. They render to Caesar the things that are Caesar's and to themselves the things that are God's - the ultimate values of justice, fair play, and holding the balance between the powers of the executive and individual rights, one of society's more difficult conjuring tricks'. ${ }^{16}$ But in reality, he explains, they 'embody, as they struggle to make finite decisions in finite situations, the sorts of contradictions which each of us lives in, placed, as we are, in political and personal situations which are structured, by our own nature and that of the societies we create, to reflect permanent and unavoidable conflicts'. ${ }^{17}$

If my first claim is that his lecture contains no new political, philosophical or methodological insights, the second is that this is unsurprising since he was not the originator. Griffith was able to present this public law method fully formed in the early 1950s because he adopted a method that he neither invented nor developed. That Griffith presented this approach in such a confident and robust manner owes much to the fact that he belongs to the third generation of a functionalist style of public law promoted at the LSE in the first half of the twentieth century. His great achievement as a scholar is to have carried forward into the post-war period a method of public law pioneered by Harold Laski and then advanced by his disciples, William Robson and Ivor Jennings.

Laski was the innovator and it is no coincidence that he spent his formative postgraduate years between 1914 and 1920 in North America. There he fully embraced the innovative methods that we come to associate with American legal realism. ${ }^{18}$ Laski's early work promoted a realist theory of the modern state. During the 1920s he provided the basic template for a modern approach to public law in Britain through studies on sovereignty, delegated legislation, administrative discretion and judicial review of social legislation. ${ }^{19} \mathrm{His}$ functional method was then advanced by William Robson, who taught at LSE from 1926 (the year Laski was promoted to the chair in political science) until his retirement in 1962, and Ivor Jennings, who joined in 1929 till 1940 (when he was appointed Vice-Chancellor of University College Ceylon).

From the late-1920s onwards, Robson and Jennings produced a prodigious body of public law works on constitutional and administrative law, and especially on public corporations, tribunals, delegated legislation, judicial review, and local government. Griffith's scholarly method was determined by the innovative work of his teachers - later senior colleagues - during the inter-war period. ${ }^{20}$ In developing this functional method, these

\footnotetext{
${ }^{14}$ JAG Griffith, 'Academic Preparation for the Practice of the Law' (1962) 14 J. of Legal Education 13-20, at 18.

15 Ibid. 19.

16 JAG Griffith, 'Judges in Politics: England' (1968) 3 Government and Opposition 485-498, at 485.

17 Ibid. 497.

18 See Neil Duxbury, Patterns of American Jurisprudence (Oxford: Clarendon Press, 1995), ch.2

19 See Martin Loughlin, Public Law and Political Theory (Oxford: Clarendon Press, 1992), 169-173.

${ }^{20}$ In the 1930s, for example, Jennings explicitly advocated the need for a new theory of law based not on the "philosophical method" but on the "sociological method": W. Ivor Jennings, The Law and the Constitution (London: University of London Press, [1933] 2nd edn. 1938), Appendix III: ‘A Note on the Theory of Law'. As he mentions in the Chorley Lecture, Griffith was taught by Jennings as an undergraduate: above n.4, 6. See also John Griffith, 'A Pilgrim's Progress' (1995) 22 J. of Law and Society 410-15, 411: Jennings ... taught me to see the important distinction between definition and description, to see that definitions created greater problems than descriptions and that this was
} 
scholars were influenced not just by a flourishing American legal realist movement but also by other modernising movements in European jurisprudence that promoted sociological, institutional and materialist approaches. ${ }^{21}$ And although Griffith did not read much European theoretical literature - an obvious exception being Laski's translation of Duguit's work on the transformation of public law 22 - his views are not far removed from the institutionalism of Hauriou and Romano, ${ }^{23}$ the materialism of Lassalle and Mortati, ${ }^{24}$ and the nominalism of Schmitt. ${ }^{25}$

I emphasise these two points about Griffith's thesis for a specific reason. His 1978 Chorley Lecture was duly feted in the twenty-first century. But those who base their claims on the foundations of Griffith's lecture generally fail to situate his arguments in an appropriate historical and political context. ${ }^{26}$ And if not properly situated, both meaning and significance are likely to be misconstrued.

\section{The Political Constitution as a Palimpsest}

In the two decades following Griffith's Chorley Lecture, it was generally recognised as a critical assessment of contemporary constitutional ideas according to the functionalist

particularly so when we had to unravel the confusions surrounding the doctrine of the separation of powers'. Robson was also one of his tutors: see JAG Griffith, 'Justice and Administrative Law Revisited' in JAG Griffith (ed), From policy to administration: essays in honour of William A. Robson (Allen \& Unwin 1976), 200-16, at 200: 'I first sat at the master's feet as an evacuee undergraduate in Cambridge [in 1939]'. He states there (at 204) that Robson 'was breaking a long-standing British tradition which insisted on there being two levels of presentation. ... On one level was advanced the view of the constitution handed down from Blackstone to Bagehot and Dicey. This consisted of a series of comfortable, liberal-democratic doctrines about the nature and functioning of the constitution ... The other was that of day-to-day reality. This reality was not to be written about.' See further Loughlin, Public Law and Political Theory, above n.19, 165181.

${ }^{21}$ See W. Ivor Jennings (ed), Modern Theories of Law (London: Oxford University Press, 1933). See further, Martin Loughlin, 'Modernism in British Public Law, 1919-79’ 2014 PL 56-67.

22 See Griffith, 'Political Constitution', above n.4, at 6: 'M. Duguit being a Frenchman and a constitutional lawyer seemed to me to present the nearest thing to a solid, positivist, unmetaphysical, non-natural foundation for analytical jurisprudence. I read him avidly. I wrote a long essay about him for my tutor Ivor Jennings who never returned it or, for all I know, read it.' See Léon Duguit, Law in the Modern State F and H Laski trans (London: Allen \& Unwin, 1921). ${ }^{23}$ Griffith, 'A Pilgrim's Progress', above n.20, at 414: 'Institutions are real, consisting not merely of the persons who form them. Like corporations (often the form they assume) they have their own existence, not only in legal theory but in the world.' Further, at 413: 'The founder of Institutional Theory was Maurice Hauriou who developed it in the early years of the century in his Précis de Droit Administratif and gave it prominence in an article in 1925, after which it became much discussed in France'. See Albert Broderick (ed), The French Institutionalists: Maurice Hauriou, Georges Renard, Joseph T. Delos (Cambridge, Mass.: Harvard University Press, 1970), Pt.I; Santi Romano, The Legal Order [1917] Mariano Croce trans. (London: Routledge, 2017).

${ }^{24}$ JAG Griffith, 'Judges and the Constitution' in Richard Rawlings (ed), Law, Society, and Economy: Centenary Essays for the London School of Economics and Political Science, 1895-1995 (Oxford: Clarendon Press, 1997), 288-310, 309: 'The structure of the society we live in determines the shape of our institutions and the way they behave. That structure is both economic and political.' Cf. Ferdinand Lassalle, 'Über Verfassungswesen' in his Gesamtwerke E. Blum ed. (Leipzig: Pfau, 1901), vol.1, 40-69; Costantino Mortati, La Costiturione in Senso Materiale (Milan: Guiffrè, 1940).

${ }^{25}$ Griffith, 'Political Constitution', above n.4, 16: 'the State is yet another metaphysic invented to conceal the reality of political power'. Cf. Carl Schmitt, The Concept of the Political G. Schwab trans. (Chicago: University of Chicago Press, 1996), 30-31: 'Words such as state, republic, society, class, as well as sovereignty, constitutional state, absolutism, dictatorship, economic planning, neutral or total state, and so on, are incomprehensible if one does not know exactly who is to be affected, combated, refuted, or negated by such a term.'

${ }^{26}$ See, eg, Thomas Poole, 'Tilting at Windmills: Truth and Illusion in "The Political Constitution"” (2007) 70 MLR 25077, where neither Robson nor Jennings are mentioned, and Laski referred to only once in a footnote on the impact of the First World War (at 263, n.85). In a subsequent paper by Poole, 'The Elegiac Tradition: Public Law and Memory' [2014] PL 68-84, Jennings is discussed but neither Laski nor Robson mentioned. 
method. As such it garnered relatively little critical attention, ${ }^{27}$ for the reason that public lawyers had more important practical and political issues to address. Functionalists conceived public law as the law of public institutions. But their descriptive method had been shaped by the underlying conviction that social progress could only be sustained through the growth in the role of public institutions staffed by professionals educated in an ethos of public service. ${ }^{28}$ Yet in the very year that Griffith's lecture was published, this tenet was seriously threatened by the election of a Conservative administration on a manifesto promising to roll back the state and restore individual freedom. ${ }^{29}$

Through four successive terms, the Conservative government promoted policies of privatisation, de-regulation and restructuring the welfare state. In Public Law and Political Theory, published in 1992, I argued that these reforms had generated a crisis of conviction among adherents to the functionalist method and that was underpinned by a more general crisis in the development of the modern administrative regulatory state during the post-war period. ${ }^{30}$ Further, these shifts were leading not only to a loss of faith in the functionalist method but also in the dominant tradition of twentieth century public law thought, which I labelled conservative normativism. These developments indicated for me why public law scholarship was in this 'curiously unsatisfactory condition'. 31 They accounted for the emergence of a different rationalist method, one Griffith had criticised as the resurgence of natural law theories and which I labelled 'liberal normativism'.

Only in the new millennium did the growing hegemony of liberal normativism lead a new generation of public law scholars to present a normatively-infused defence of the British constitution constructed on different premises. In doing so, a peculiar thing happened: Griffith's Chorley Lecture was adopted as a palimpsest of the new movement. The revisionists adopted the lecture as a symbolic expression of something quite different from what Griffith had intended. The expression 'the political constitution’ signified for Griffith an empirical method of studying the constitution of a polity shaped by the interplay of political forces. But this was repackaged as an alternative normative theory. Griffith's orthodox functional analysis was converted into what Graham Gee and Grégoire Webber called a 'novel account of Britain's constitutional arrangements' which 'laid the foundations for the emergence of the idea of the political constitution as a fresh and provocative way of thinking and talking about the British constitution'. ${ }^{32}$ The 'political constitution' was transformed into

\footnotetext{
${ }^{27}$ Google scholar records 416 citations to the article: during the first twenty years there were 86 citations and since 2000, 325 (accessed: 3 November 2017).

${ }^{28}$ See, eg, JAG Griffith, Central Departments and Local Authorities (London: Allen \& Unwin, 1966), 534: 'The professionalism of local government officers is the greatest single force which enables local authorities to carry out, with much efficiency, the considerable tasks entrusted to them. And pride in a profession is a better insurance of highclass performance than more material interests.'

${ }_{29}$ Conservative Election Manifesto 1979, Foreword (Rt Hon Margaret Thatcher): 'No one who has lived in this country during the last five years can fail to be aware of how the balance of our society has been increasingly tilted in favour of the State at the expense of individual freedom. This election may be the last chance we have to reverse that process, to restore the balance of power in favour of the people. It is therefore the most crucial election since the war.'

30 See Loughlin, Public Law and Political Theory, above n.19, ch.9. For general analyses of crisis of the period see: Jürgen Habermas, Legitimation Crisis (Boston: Beacon Press, 1975); James O'Connor, The Fiscal Crisis of the State (New York: St Martin's Press,1973); Robert Bacon \& WA Eltis, Britain's Economic Problem: Too Few Producers (London: Macmillan, 1976); Mancur Olson, The Rise and Decline of Nations. Economic Growth, Stagflation and Social Rigidities_(New Haven: Yale University Press, 1982); SH Beer, Britain Against Itself: The political contradictions of collectivism (London: Faber, 1982); Anthony King, 'Overload: problems of governing in the 1970s' (1975) 23 Political Studies 283-96; James Douglas, 'The Overloaded Crown' (1976) 6 British Journal of Political Science 483-505; Claus Offe, "Ungovernability": the renaissance of conservative theories of crisis' in his Contradictions of the Welfare State (London: Hutchinson, 1984), ch.2.

${ }^{31}$ Loughlin, Public Law and Political Theory, above n.19, 1.

32 Graham Gee and Grégoire Webber, 'What is a Political Constitution?' (2010) 30 OJLS 273-299 at 277.
} 
'political constitutionalism' and in this guise was presented as a phenomenon set in opposition to something called 'the legal constitution'.

This is a strange manoeuvre. It caused my colleague Thomas Poole in 2007 to suggest that, far from being the last gasp of a method whose days were numbered, 'The Political Constitution' was Griffith's 'most important and influential work' and had 'become a founding text of an influential style of public law thinking' called 'political constitutionalism'. ${ }^{33}$ But it was equally strange that as a consequence of this manoeuvre constitutional analysis was converted into an adversarial contest, a quarrel over 'the legal' versus 'the political' constitution. ${ }^{34}$ As I noted in 2006, the question 'is not whether we have a legal or political constitution: it is how the idea of law within the political constitution (i.e., the constitution of the polity) might best be conceptualized'. ${ }^{35}$ The formulation 'legal v. political' was doomed to lead to an entirely fruitless debate.

\section{The Rise and Fall of Political Constitutionalism?}

The main advocate of 'political constitutionalism' was Adam Tomkins. Concerned with the growing influence of the liberal normativist style of public law now re-labelled 'legal constitutionalism', Tomkins has since the late-1990s been searching for alternative ways of expressing the theoretical basis of British constitutional practice.

His first iteration was a defence of what in 1998 he called the 'parliamentary constitution', ${ }^{36}$ subsequently amplified by his suggestion that the British constitution contains a 'bi-polar separation of power ... not between legislature, executive, and judiciary, but between the Crown and Parliament'. ${ }^{37}$ These formulations, however, are thoroughly orthodox, being compatible with both the standard narrative of conservative normativism expounded by Dicey and his followers and by the functionalist account. ${ }^{38}$ In 2002, Tomkins made a more ambitious claim for the normative authority of what he called the 'political constitution', 39 and this was extended in 2005 by his advocacy of 'our republican constitution'. ${ }^{40}$ It is these later innovations that are of particular relevance to Griffith's account of the political constitution.

Tomkins' advocacy of the political constitution in 2002 began by invoking Harlow and Rawlings' red-light/green-light imagery to indicate that public lawyers have become

\footnotetext{
33 Poole, 'Tilting at Windmills?' above n.26, at 250, 251. Poole is not alone in this historical revisionism. See, eg, Paul Scott, '(Political) constitutions and (political) constitutionalism' (2013) German LJ 2157-83, at 2162: 'It is no coincidence that the political constitution as a phenomenon was identified by Griffith in part as a response to, among others, Ronald Dworkin.'

34 See Adam Tomkins, 'In Defence of the Political Constitution' (2002) 22 OJLS 157-75; Tom R. Hickman, 'In

Defence of the Legal Constitution' (2005) 55 University of Toronto LJ 981-1022.

35 Martin Loughlin, 'Towards a Republican Revival?' (2006) 26 Oxford J. of Legal Studs 425-37, at 435-6.

36 Adam Tomkins, The Constitution After Scott: Government Unwrapped (Oxford: Clarendon Press, 1998), 266-

75, 'Conclusion: Reforming the Parliamentary Constitution'.

37 Adam Tomkins, Public Law (Oxford: Oxford University Press, 2003), 46-47.

38 See, eg, James Mill, An Essay on Government, [1820] Ernest Barker intro. (Cambridge: Cambridge University Press, 1937); John Stuart Mill, Considerations on Representative Government [1861] in his Three Essays (Oxford: Oxford University Press, 1975), 145-423, esp.211-228; Bagehot, above n3, 151 ('The whole life of English politics is the action and reaction between the Ministry and the Parliament.'); Griffith, 'The Place of Parliament', above n.9.

39 Tomkins, Public Law, above n.37, 18-24.

40 Adam Tomkins, Our Republican Constitution (Oxford: Hart, 2005).
} 
accustomed to thinking of their subject 'in terms of competing schools of thought'. ${ }^{41}$ This was unpropitious since this simile, treating judicial review like traffic lights, is incapable of providing a robust theoretical foundation of British public law and the fact that it has been widely adopted is indicative of contemporary problems. ${ }^{42}$ Tomkins then explained that the British state 'has been based on a political constitution, but over the past thirty years the tradition of the political constitution has come under pressure from the rival theory of legal constitutionalism' '.43 Tomkins here is evidently using the term 'the political constitution' as a synonym for a 'parliamentary constitution'. This leads him to argue that because of the growing influence of legal constitutionalism, the alternative of political constitutionalism must be defended on normative grounds. A 'revolution is happening' he claims: 'The constitution is up for grabs, and it is the judges who are grabbing it'. ${ }^{4}$

The problem with Tomkins' search for an alternative normative account of the British constitution is that he converts Griffith's Chorley Lecture into something it is not, namely, 'the most important statement on the political model of constitutionalism'. ${ }^{45} \mathrm{He}$ then advances his account from what he perceives to be deficiencies in Griffith's presentation of that 'model'. He contends that Griffith's (so-called) 'defence of the political constitution' is 'entirely descriptive' and is deficient because Griffith 'did not believe the political model of accountability to be constitutionally required, still less constitutionally entrenched'. ${ }^{46}$

These are, to my mind, errors. Griffith's account was not 'entirely' descriptive; it was based on a Comtean belief in continuing social progress. It was neither a 'defence' nor a 'model'; it was an explanation. And given his views on the nature of the constitution, Griffith's account could never have risen to the level of being 'constitutionally required'. Tomkins seeks to convert Griffith's functional method into a 'model' for the purpose of grounding it 'in theory' and explaining 'the norms and values on which the model was founded'. ${ }^{47}$ He perceives this to be required because Griffith's method, although 'developed by people who were largely progressive in their personal politics, was not founded on progressive values. It is functionalist, or descriptive, in nature, rather than normative'. ${ }^{48}$

Tomkins' ambitious aim is to show that the legal constitutionalist account is not just distorted; it is 'unconstitutional'. ${ }^{49}$ In order to deliver on this ambition he had to demonstrate that republicanism offers a better account of the fundamental values underpinning the British constitution..$^{50} \mathrm{I}$ have argued elsewhere that he does not achieve that objective. ${ }^{51}$ This cannot be done without a skewed reading of modern political developments, thereby engaging in precisely the type of exercise - a Romantic argument of retrogressive progress -

\footnotetext{
41 Tomkins, 'In Defence', above n.34, 157.

42 Although Harlow and Rawlings use it only as a teaching technique, others have elevated it into a theoretical framework of public law: Carol Harlow and Richard Rawlings, Law and Administration (Cambridge: Cambridge University Press, $3^{\text {rd }}$ edn. 2009). It cannot provide a theoretical foundation of public law because this traffic-light imagery conceives law entirely as an instrumental technique. This might work for Griffith, but will not be supported by those who reject the functionalist method.

43 Public Law, 21.

44 Public Law, 23.

45 Tomkins, Our Republican Constitution, above n.40, at 36.

46 Ibid. 38.

47 Ibid. 40.

48 Ibid. 39. Tomkins also states: 'American legal realism reached its height from the 1920s to the 1940s, but its insights did not appear to penetrate British public law scholarship until the $1970 \mathrm{~s}$... Only at this point did British constitutional commentators such as John Griffith start to point out that judicial law-making is just as much a political enterprise as is parliamentary law-making' (ibid. 12). This is a curiously inaccurate statement. Cf. Loughlin, Public Law and Political Theory, above n.19, 126-37, 165-76.

${ }^{49}$ Tomkins, ibid. 40.

50 Ibid 131: 'the republican values on which our political constitution was founded'.

51 Loughlin, 'Towards a Republican Revival?', above n.35.
} 
for which he (rightly) criticises legal constitutionalists. But he also fails to appreciate that since republicans accord law a central place in their theories, no republican reading of the constitution is possible without embracing some version of the legal constitutionalism he criticises.

Griffith recognised only too well that the evolved parliamentary constitution rests on a system of government far removed from the republicanism Tomkins promotes. ${ }^{52} \mathrm{He}$ was suspicious of those who, in the course of describing, eulogised parliamentary practices. ${ }^{53}$ And his account of politics was more sober than the normative conception Tomkins advocates; where Tomkins talks of politics as a practice to 'be celebrated' and which 'makes us free' and 'makes us human', ${ }^{54}$ Griffith sees a set of practices generated as a consequence of the 'wearisome condition of humanity'. ${ }^{55}$ Whatever the virtues of Tomkins' project, there is little evidence to support it in Griffith's work.

By 2010, Gee and Webber were telling us that it is commonplace ... for textbooks and articles to juxtapose the idea of a political constitution with that of a legal constitution'. ${ }^{56}$ If that is correct, it reveals the impoverishment of public law thought. Significantly, it was not long after this that Tomkins entirely resiled from his own argument. Writing in 2013, he suggested that the 'model of the political constitution has frequently been contrasted with that of the legal constitution' and the relationship between the two 'has typically been presented as ... competing models ... doing battle not just for primacy but, it seems, for exclusivity'. ${ }^{57}$ He would know because these are his own declarations. He then baldly asserts that such claims are now 'outdated' and should be replaced by 'the revised view', one that conceives the British constitution as a 'mixed constitution' of 'politics and law'.58

'If we are to understand the contemporary British constitution', Tomkins declares, 'we must understand both its political and its legal dimensions' and '[a]ny account of the constitution that presented only one of these aspects would necessarily fail'. ${ }^{59}$ 'I do not want to go back to the political constitution', he concludes, since the 'mixed constitution is better'. ${ }^{60}$ This is quite a retreat. It leaves a series of puzzles unresolved. What remains of his republican project? What remains of his argument that the British have a bi-polar constitution in which 'the courts are, in some sense, part of, or dependent on, the Crown, and are not independent of it'? ${ }^{61}$ Does he continue to maintain that the practice of politics 'makes us free' and 'makes us human'? According to what criteria does he now think the 'mixed constitution' is 'better'? Is his latest pronouncement descriptive or normative? And to what extent does this signal his return to the orthodox view of the British constitution as a 'parliamentary constitution'?

\footnotetext{
52 Griffith, 'Place of Parliament, Pt.I', above n.9, at 279: 'It may be that the emergence of responsible and representative government in the eighteenth and nineteenth centuries rests on the Revolution of 1688; but it is ludicrous to ignore this emergence and to suggest that political developments in the twentieth century are set against the same backcloth as those of the seventeenth century'.

53 Griffith, ibid. 279: 'We are reluctant to admit in public that it [parliamentary democracy] has any shortcomings in its present form. When we compare it to other forms of government we become Blackstonian in our adulation'.

54 Tomkins, 'In Defence of the Political Constitution', above n.34, 172.

55 Griffith, 'Political Constitution', above n.4, 3.

${ }^{56}$ Gee and Webber, above n.32, 273.

${ }^{57}$ Adam Tomkins, 'What's Left of the Political Constitution?’ (2013) 14 German Law Journal 2275-92, at 2275.

58 Ibid. 2275-6.

${ }^{59}$ Ibid. 2276.

${ }^{60}$ Ibid. 2292.

${ }^{61}$ Tomkins, above n.37, 54-5.
} 


\section{Vi. Political Constitutionalism Reconstituted}

Tomkins is not the only scholar who has used Griffith's lecture as the basis for an alternative normative account of the British constitution. A second strand espouses 'political constitutionalism' but does not tie it to a claim about republicanism. This strand has been most coherently developed by Graham Gee. In 2008, Gee presented what he calls variously a 'defence and partial reconstruction' and a 'reconstruction and partial defence' of Griffith's 'political constitutionalism'. ${ }^{2}$ In this article, Gee criticises what he rightly perceives as a 'tendency to caricature Griffith's work', but then proceeds to call Griffith 'the archetypal political constitutionalist', thereby contributing to that tendency. ${ }^{63}$ Gee claims that 'while 30 years ago unnerving in their unorthodoxy', Griffith's ideas can today appear 'clichéd'. ${ }^{64}$ But is the opposite not actually the case? Thirty years ago they were understood as an orthodox statement of the functional method whereas today, through misrepresentation, they are repackaged in a clichéd form.

Gee's main objective is to reconstruct the 'dissenting tradition' of functionalism as 'political constitutionalism'. ${ }^{65}$ Claiming that Griffith has an 'underdeveloped account of politics' that needs reconstruction, he begins by criticising Poole's claim that Griffith's comment that 'the constitution is what happens' results in 'stripping the entity it describes of any real meaning. ${ }^{6}$ Gee is correct, though it is surprising how many political constitutionalists have been entranced by the so-called 'Griffith aphorism'. After all, it is merely a pithy formulation of what has been the orthodox understanding of the British constitution over the last 250 years. ${ }^{67}$

Yet the main aim of Gee's article is to present an alternative to Tomkin's republicanism. He finds this in Michael Oakeshott's account of politics. ${ }^{68}$ Gee claims there is an 'obvious irony' in making a connection between Griffith and Oakeshott's views of political activity, but this is not self-evident. ${ }^{69}$ Both believed that politics is rooted in practice, that is, in

\footnotetext{
${ }^{62}$ Graham Gee, 'The political constitutionalism of JAG Griffith' (2008) 28 Legal Studies 20-45, at 20, 22.

63 Ibid. 21.

${ }^{64}$ Ibid. 22.

65 Ibid. 21-2.

${ }^{66}$ Poole, above n.26, 275; Gee, ibid. 32-37.

${ }^{67}$ For evidence that Griffith's claim that the constitution is 'what happens', which he first stated in 1963, is in no sense novel or unorthodox see, eg, Bagehot, above n.3, 267: 'There is a great difficulty in the way of a writer who attempts to sketch a living Constitution ... The difficulty is that the object is in constant change. ... [A] contemporary writer who tries to paint what is before him is puzzled and perplexed: what he sees is changing daily'; AV Dicey, Introduction to the Study of the Law of the Constitution (London: Macmillan, $8^{\text {th }}$ edn 1915), 85-86: 'The constitution, he [Tocqueville] seems to have thought, was changeable because it was not reduced to a written or statutory form. It is far nearer the truth to assert that the constitution has never been reduced to a written or statutory form because each and every part of it is changeable at the will of Parliament'; W. Ivor Jennings, Cabinet Government (Cambridge: Cambridge University Press, 1 st edn. 1936), xii: 'the British constitution is changing so rapidly that it is difficult to keep pace with it'; JP Mackintosh, The British Cabinet (London: Stevens, 1962), 534: 'In fact, all of our institutions change as British society and world conditions alter.'; Graeme C. Moodie, The Government of Great Britain (London: Methuen, 1964), 16: 'the British constitution is thus a continuously changing blend of the ancient and modern'. Are any of these views new? See the (anonymous) review of Cato, An Essay on the Constitution of England (1765): 'There is scarce a word so frequently used, and so little understood as the word Constitution. If nothing more is intended by it than to express the several component parts of Government ... all men must agree about its signification: but if we take into the idea the several powers vested in those orders, it will then be difficult to define it. Indeed taking the word to include the latter idea, it does not admit of a precise and permanent definition; for as those powers are liable to fluctuate from a variety of adventitious circumstances, which make the political scale at different times preponderate in favour of different parties, what is called the Constitution must necessarily vary with every accidental change.' (Monthy Review, or Literary Journal, Jan. 1765: 72 British Periodicals 59).

${ }^{68}$ Gee, above n.62, 23.

${ }^{69}$ Ibid. 38.
} 
experience; both believed that theories of politics are false in that they are rationalisations of experience; and both saw politics as an expression of what we do, not what ought to be done. ${ }^{70} \mathrm{But}$ - and this is critical - the association between the two is more contentious if one conflates similarities in their view of the nature of political activity with similarities in their political views. Gee is careful not to conflate their political views, helpfully accentuating some of the traditional aspects of Griffith's socialist orientation. But the analogy is an uncomfortable one and the question is: what is to be gained by this comparison?

I have an answer which requires me to return to the framework of Public Law and Political Theory. In arguing that public law discourse was bifurcated, I maintained that between the two basic styles of normativism and functionalism there is no underlying agreement on the boundaries and contours of the subject. A scholar's argument is always situated within a political tradition. I suggested that the dominant tradition has been a conservative variant of normativism. This adheres to the common law method with its distaste for system and finds its political expression in the unwritten British constitution. I explained that this tradition, whose philosophical foundations are best expressed by Oakeshott, progressively loses its authority in the twentieth century because of its inability to respond constructively to the rise of democracy and the growth in government.

For much of the twentieth century, the intellectual alternative to conservative normativism came from a functional method which embraced democracy and the administrative state while advocating new institutional arrangements to respond effectively to the modern order of government. In this worldview, the common law was perceived as a core element of the problem of adaptation, badly in need of replacement by a rational system of administrative law. But just as conservative normativism had failed to respond to modern developments, functionalism was found wanting when, conceiving law as a means to an end, it was felt to possess no critical legal resources to address the political issues arising when governmental powers were used to retrench. It was the crises within these two traditions that provided the conceptual space for a liberal variant of normativism to emerge. In these circumstances law was transformed from precedent or instrument into a general moral concept requiring fidelity not just to rules but to the principles of fairness and justice that legal rules presuppose. ${ }^{71}$

Griffith's lecture marks the last gasp of functionalism. The functionalist style had been underwritten by Fabian socialist principles, with the continuous growth of the public sector a sign of continuing social progress. By the end of the 1960s however, Griffith was expressing his sense of disillusion about the movement. Aspects of a provocatively-titled essay of his from that period support the case for radical constitutional reform, though reform of a different nature from Hailsham's conservative and Scarman's liberal advocacy during the 1970s. In 'Why we need a Revolution', Griffith argues that the 'intractability of the present constitutional set-up, the reason why nothing short of a revolution will do the trick is evidenced ... [by lack of radical ideas in various proposals for reforms]'.72 But his realism or pessimism soon comes to the fore: 'This demand is unlikely to be met because there are no

\footnotetext{
70 Their views are outlined in Public Law and Political Theory, above n.19, 64-83, 197-201. Evidence that Griffith could be situated in this way of thinking about political practice can be gleaned from his admiration for the lectures of the former Conservative MP, Leo Amery: LS Amery, Thoughts on the Constitution (London: Oxford University Press, 1948). See Griffith, 'Delegated Legislation', above n.7, 1081 (n5): 'I take this opportunity of acknowledging my debt to this brilliant analysis'.

${ }^{71}$ Loughlin, Public Law and Political Theory, above n.19, 230-40.

${ }^{72}$ JAG Griffith, 'Why we need a Revolution' in Bernard Crick and William A. Robson (eds) Protest and Discontent (London: Pelican, 1970), 25-36, at 31.
} 
ways of meeting it within the political and economic system'. ${ }^{73}$ Consequently, revolution is necessary 'as the only alternative now that reformism has not simply failed but has been shown to be incapable of success' ${ }^{74}$ This unspecific appeal, it should be emphasised, was born of disappointment: 'We are not struggling towards the summit, impeded by those who wish to prevent us from reaching it' but simply 'struggling to avoid slipping further down the slope'. ${ }^{75} \mathrm{He}$ concludes somewhat implausibly by claiming that 'I have a disposition to be utopian'. ${ }^{76}$ There is little evidence of this in his other writing, nor a decade later in his Chorley lecture. And for this reason, I would suggest that he is the last of the Fabian public lawyers. ${ }^{77}$

This has been a rather circuitous way of coming to my main point about the postrepublican reconstitution of so-called 'political constitutionalism'. Far from being a continuation of Griffith's functionalist method, political constitutionalism is an attempt to revive the conservative normativist project in the twenty-first century. Contrary to Gee's claim to be reconstructing the dissenting tradition of functionalism as political constitutionalism, the movement promoted by Tomkins in his post-republican phase, and by Gee, Webber and others seeks to reconstitute and restore the authority of conservative normativism. Having lost the support of the judiciary now that the traditional guardians of conservative normativist values have been won over to liberal normativism, conservative normativists, assuming the mantle of political constitutionalists, now seek to bolster the authority of Parliament.

In this endeavour, they have received support from some powerful quarters. In a series of well-publicised public lectures, for example, Lord Sumption has warned that the biggest problem facing the judiciary today is that of preserving the traditional boundary between politics and law. ${ }^{78}$ The political constitutionalists have now coalesced as a group around a 'Judicial Power Project' funded by the Conservative-orientated think tank, Policy Exchange.79 They may well be raising important issues for discussion, but my point is that their conceptions of law and constitution and their political orientation diverge in important respects from Griffith's arguments in 'The Political Constitution'. The similarities are superficial, the differences profound. Those differences are highlighted by Griffith in one of his last essays in which he sums up his concerns about contemporary trends:

The mistake is to take individual rights seriously and social inequalities lightly. Today we live in a period of economic and political decline and of institutional collapse. Because of this there is much talk of constitutional reform. But it is directed not to

\footnotetext{
73 Ibid. 35.

${ }^{74}$ Ibid. 36

75 Ibid. 36

76 Ibid. 36.

77 Cf. Griffith, 'Justice and Administrative Law Revisited', above n.20, at 201: 'this has been his [Robson's] manner and style throughout, as it was with so many of his contemporaries. But like them - especially the Webbs - strong political feeling kept breaking through, not necessarily or even often to damage the objectivity of the analysis but to provide its motive and to inform it. He is the last of the Fabians.'

78 See Jonathan Sumption QC, 'Judicial and Political Decision-Making: The Uncertain Boundary' FA Mann Lecture, 2011; Lord Sumption, 'Foreign Affairs in the English Courts since 9/11', lecture at the LSE, 14 May 2012; Lord Sumption, 'The Limits of Law' in NW Barber, Richard Ekins and Paul Yowell (eds), Lord Sumption and the Limits of the Law (Oxford: Hart, 2016), ch.2. See further Martin Loughlin, 'Sumption's Assumptions' in Barber et al ibid., ch.3.

${ }^{79}$ The Wikipedia entry for Policy Exchange states it is 'the largest, but also the most influential think tank on the right' (source: Daily Telegraph), and is 'a neo liberal lobby group funded by dark money' (The Guardian). Graham Gee is a prominent member, acting as the Project's website editor and contributing several blogposts. Richard Ekins, Oxford University, is the Project Director.
} 
the betterment of the majority of the population but to the strengthening of the privileges of the few. 80

These contemporary controversies have at least two dimensions: institutional relations and political impact. Griffith's views on public law harnessed law as a means to the end of promoting equality and justice. He was sceptical about the rise of judicial power, but this scepticism was situated within a broader institutional analysis that gets little attention from today's political constitutionalists. And if they do not retain that link between means and ends, they remain far removed from Griffith's functionalist account of the political constitution.

\section{CONCLUSION}

My objective in revisiting Griffith's Chorley Lecture has been to suggest that its meaning and significance must be situated within its intellectual and political context. 'The Political Constitution', far from presenting a novel analysis, was a critical account of contemporary constitutional ideas from the perspective of a well-established functionalist public law method. It has been adopted by a new generation of public law scholars as a call-to-arms against the hegemony of liberal normativism/legal constitutionalism but this has entailed significantly distorting his argument. Griffith might not have been unhappy about that: better to be misread for justified political purposes, he could well have said, than ignored because of the strictures of an austere juristic method. But if the discipline is to develop, we must acknowledge the nature of the manoeuvres being made in these reconstructions of Griffith's arguments. The value of historical knowledge after all is not that it tells us how to succeed. Rather, it tells us what we have become.

${ }^{80}$ Griffith, 'Judges and Constitution', above n.24, at 310. 